\title{
LA ACTIVIDAD ESCULTÓRICA DE HUGUET BARXA. NUEVAS PERSPECTIVAS
}

\author{
ANTÒNIA JUAN ViCENS \\ Universidad de las Islas Baleares
}

\begin{abstract}
Huguet Barxa (1427-1462) es uno de los escultores de la Baja Edad Media mallorquina más conocidos. No obstante, es una figura todavía un tanto enigmática y controvertida, por lo que respecta al conjunto de obra que se le atribuye. El presente artículo pretende ofrecer una nueva visión sobre la actividad escultórica de este autor. Se cuestionarán algunas hipótesis que tradicionalmente se habían aceptado como válidas, como la atribución del retablo de la Passio Imaginis, y se adscribirá a su catálogo un conjunto de obras que hasta hoy habían permanecido en el anonimato.
\end{abstract}

Palabras clave: Huguet Barxa; Mallorca; Escultor; Escultura gótica; Escultura arquitectónica; Baja Edad Media.

\section{THE SCULPTURAL ACTIVITIES OF HUGUET BARXA. NEW PERSPECTIVES}

Huguet Barxa (1427-1462) is one of the best-known sculptors of the Late Middle Ages in Mallorca. Nevertheless, he is still a somewhat enigmatic and controversial figure as concerns the body of work attributed to him. The present article aims to offer new insight into the sculptural activities of this artist. Some hypotheses that had traditionally been accepted as valid are questioned, such as the attribution to him of the Passio Imaginis altarpiece. A group of works that until now had remained anonymous are here ascribed to his catalogue.

Key words: Huguet Barxa; Majorca; Sculptor; Gothic sculpture; Architectural sculpture; Late Middle Ages.

Huguet Barxa (1427-1462 †) es uno de los escultores más conocidos y destacados de Mallorca de la Baja Edad Media, y a la vez uno de los más enigmáticos. Igualmente, se erige en un ejemplo paradigmático de la versatilidad del artesano medieval. El corpus de documentación localizada relativa a su trayectoria vital y profesional permite afirmar tanto lo primero como lo segundo. Pese a ello, sólo se ha conservado una única obra documentada. Se trata de la conocida escultura de Santa Práxedes, sita en la capilla de Santa Ana del palacio de la Almudaina de Palma. Fue precisamente en base a esta pieza que se le atribuyó un corpus de obra específico. Actualmente, éste precisa de una revisión, puesto que algunas de las esculturas que se le adscriben no siempre guardan relación directa con su estilo. 
En el presente trabajo, aunque se incidirá sobre su actividad escultórica, no se obviarán otras facetas de su personalidad artística, puesto que es preciso abordar la figura de Huguet Barxa de forma completa para comprenderlo y conocerlo en su totalidad. Ello es necesario no sólo para actualizar y ampliar con nuevos datos el artículo que en su día le dedicó Gabriel Llompart ${ }^{1}$ sino también para reunir, y en ciertos casos matizar y/o descartar, determinadas conclusiones reflejadas en estudios que, de forma parcial, se han ocupado de Barxa a lo largo de estos años. También es objetivo del presente trabajo, a partir del análisis estilístico o bien a partir de la interpretación documental, incorporar a su catálogo un conjunto de obras que actualmente restan en el anonimato $^{2}$.

\section{Posible origen de Barxa y su llegada a Mallorca}

Como se acaba de decir, Huguet Barxa es un personaje enigmático. Ello se debe a que desconocemos su procedencia y sus orígenes formativos, datos que podrían ayudar a esclarecer y delimitar la naturaleza de su estilo. Con todo, se le ha venido considerando tradicionalmente como un artista extranjero, en base a dos motivos. En primer lugar, porque el apellido "Barxa" es poco frecuente en Mallorca; de hecho él es el único artesano de la piedra documentado que se apellida así. Gabriel Llompart afirma que en catalán antiguo "Barxa" se refiere a una embarcación, y el mismo autor apunta la posibilidad que el apellido en cuestión tenga un origen francés ${ }^{3}$. En segundo lugar, porque algunas de las primeras referencias que constan sobre él (1428 y 1430) ${ }^{4}$ lo sitúan en la órbita de Guillem Sagrera cuando este trabajaba en la construcción de la Lonja ${ }^{5}$, donde se sabe contó con la colaboración de maestros extranjeros ${ }^{6}$. Fue esto último, precisamente, lo que llevó a los investigadores a considerar que Huguet Barxa formaría parte del grupo de artesanos de la piedra extranjeros que participaron activamente en la erección de la lonja mallorquina ${ }^{7}$.

Personalmente, coincido con ambos presupuestos. Por lo que respecta al primero, es decir, el supuesto apelativo extranjero del escultor $-\mathrm{y}$ al margen de lo apuntado en su día por Gabriel Llompart-, cabe señalar que "Barxa" también está relacionado con un topónimo sardo, relativo a un lago y a una ciudad ${ }^{8}$. Ello no equivale a decir que Huguet Barxa sea sardo, aunque se trate de una opción que nunca había sido contemplada y que merecería ser tenida en consideración. En cuanto al segundo presupuesto: su participación en la Lonja, pese a que no hay documentación explícita de su intervención en la construcción del edificio, es posible adscribirle, como se detallará más adelante, alguna de las claves de bóveda de la gran sala. Puede, incluso, que fuese la Lonja el reclamo que llevó a Barxa a trasladarse a la isla, donde residiría hasta su muerte.

\footnotetext{
1 LLOMPART, 1977: 328-335.

2 En este artículo se retoman y revisan algunas de las hipótesis planteadas en mi tesis doctoral: JUAN ViCENS, 2012.

3 LLOMPART, 1998-1999: 53.

${ }^{4}$ Llompart, 1977: 53. MANote, 1996: 806.

5 Sobre este edificio véase Climent GUIMERÁ, 2003.

${ }^{6}$ Me refiero en concreto al francés Pere Auttor (LlOMPart, 1973: 100).

7 Llompart y Palou, 2000: 411. Manote, 1998: 261, nota 1.

8 Armangué i Herrero, 2007:11. Hay que tener en cuenta que en la actualidad existen en Galicia, concretamente cerca de la frontera con Portugal, algunos pueblos llamados Barxa. No obstante, me inclino a pensar, atendiendo a las estrechas relaciones entre Mallorca y Cerdeña durante la Baja Edad Media, que en todo caso Huguet Barxa tendría un origen más italiano que no gallego.
} 


\section{La versatilidad profesional de Huguet Barxa}

Por lo que respecta al panorama isleño, Huguet Barxa se erige en uno de los artistas más paradigmáticos para comprender la versatilidad y el carácter polifacético del artesano medieval. La cantidad y variedad de encargos que recibió a lo largo de su trayectoria profesional lo acreditan como uno de los artesanos más solicitados y valorados del contexto. Entre los trabajos que tiene documentados se cuenta su intervención en obras de arquitectura religiosa, la reforma de viviendas de particulares, obras escultóricas de diversa técnica y tipología e incluso, según se desprende de su inventario, estaba capacitado para montar vitrales, a la vez que tenía nociones de relojería ${ }^{9}$. En cuanto a esto último, es significativo un documento datado el 9 de julio de 1441 por el cual sabemos que cada año en la fiesta de San Juan recibía quince libras de manos de los defensores del Colegio de Mercaderes de Palma en concepto de gobernando et administrando lo $o\left(\right.$ ?) rolotga lotgie dicti collegii ${ }^{10}$. En este sentido podríamos equiparar a Huguet Barxa con el polifacético maestro valenciano Joan del Poyo, de quien sabemos que construyó y se encargó del mantenimiento del reloj del Micalet de la catedral de Valencia ${ }^{11}$.

Respecto a su intervención en obras de naturaleza arquitectónica, aunque en cierto modo ésta fue limitada, tenemos constancia documental que se encargó de la construcción de la antigua iglesia del convento de Santa Isabel de Palma $(c .1448)^{12}$. Del mismo modo, también en la década de los cuarenta, trabajó en la iglesia del convento de los franciscanos observantes de Palma de Mallorca, más conocido como de Jesús Extramuros, que llevó a cabo junto a Antoni Sagrera ${ }^{13}$.

En cambio, fueron sin duda los trabajos escultóricos los que ocuparon la mayor parte de su actividad profesional. Entre los documentados, la producción más abundante fueron las cruces de término. Hay constancia de una cruz realizada para la curia eclesiástica mallorquina $(1436)^{14}$ y de dos en la parroquia de Llucmajor, una fechada el $1436^{15}$ y la otra el $1460^{16}$.

Sus actividades también comprendían la talla de escultura arquitectónica. Al respecto, se cuentan los ángeles tenantes con la heráldica del mercader Ferrer Miró que contrató junto con el lapiscida Bartomeu Pons (febrero de 1440) ${ }^{17}$ y una gárgola que ejecutó para la catedral (1444) ${ }^{18}$.

Con independencia de las labores escultóricas en piedra, cabe decir que Huguet Barxa trabajó igualmente la madera. De hecho, en este material esculpió su única obra documentada y conservada: la Santa Práxedes de la Almudaina (1458-1460) ${ }^{19}$.

En relación a este tipo de labores escultóricas, quisiera poner énfasis en un dato extraído por Jaume Sastre del libro de fábrica de la catedral correspondiente a 1427-1428. En él se especifica

9 LlOMPART, 1998-1999: 53.

10 Archivo del Reino de Mallorca (ARM), Protocolo S-29, f. 81v. Agradezco la referencia a Magdalena Cerdà.

11 Serra Desfilis, 1994: 117.

12 LlOMPART, 1988: 48-49.

13 Carbonell Buades, 2007-2008: 67.

14 LlOMPART, 1977: 329, nota 4.

15 Muntaner Bujosa, 1962: 17-18. Llompart, 1973: 24-25.

16 BARCEló y LlOMPART, 1998: 91, doc. 10.

17 Llompart, 1977: 329-330, nota 9. Barceló Crespí, 2003: 222-223. Cabe decir que Gabriel Llompart data el contrato de obra en 1438, la revisión del documento original constata que la fecha es de 1440.

18 Archivo Capitular de Mallorca (ACM), Libro de Fábrica 1745, f. 50v. Dicha gárgola fue esculpida para ser ubicada en uno de los contrafuertes de la fachada meridional. Atendiendo al avance de las obras, es posible que se correspondiese con el tercero o el cuarto contando desde la cabecera. Lamentablemente, si en realidad la documentación se refiere a uno de estos dos, las gárgolas que los decoran están, una fragmentada, y la otra no presenta decoración figurativa.

19 Aguiló, 1905-1907: 29-30.

Arch. esp. arte, LXXXVII, 347, JULIO-SEPTIEMBRE 2014, 209-226

ISSN: 0004-0428, eISSN: 1988-8511, doi: 10.3989/aearte.2014.14 
que el 11 de mayo (1427) se le abona cierta cantidad a un tal maestro Huguet ${ }^{20}$. Es preciso identificar a dicho maestro Huguet con Huguet Barxa, no sólo porque no consta ningún otro activo en la isla con este nombre sino también por las constatadas relaciones que mantuvo con la fábrica catedralicia $^{21}$. La fecha es, además, muy significativa, no sólo porque se corresponda con el momento en que Guillem Sagrera ejercía el cargo de maestro mayor de la catedral -y de la Lonja- sino también porque coincide cronológicamente con la primera fecha donde puede constatarse una relación documental entre ambos ( 24 de abril de 1428$)^{22}$. Por lo que respecta a su actuación, parece ser que se limitó a reparar uno de los ángeles ubicados en el altar mayor. Dicho ángel podría tratarse de uno de los dos que fueron ejecutados por Llorenç Tosquella el joven en $1418^{23}$ y que, según la opinión de determinados autores, son aquellos que actualmente flanquean la cátedra episcopal ${ }^{24}$.

Siguiendo con los trabajos en madera, cabe señalar que éstos no se reducían a la factura y/o reparación de imaginería sino que se ampliaban a la ejecución y traza de estructuras (o armazones) de retablos ${ }^{25}$, así como otros trabajos menores, entre los que cabe mencionar la factura de un lecho ${ }^{26}$. Como vemos, un amplio radio de actuación que le permitía tener acceso a la contratación de un número considerable de obras de variada tipología y función.

Ser capaz de trabajar con diferentes materiales y de aplicar diversas técnicas ofrecía a los artesanos la posibilidad de recibir un número superior de encargos de los que hubiesen recibido de no ser capaces de hacerlo. Como resulta obvio, ello repercutía en su economía, puesto que el hecho de estar capacitados para intervenir en proyectos de variada índole implicaba reducir el intervalo de tiempo que, de no ser así, hubiesen estado inactivos. Podría afirmarse que la óptima aptitud para trabajar en distintas áreas era un modo de luchar en contra de la precariedad laboral ${ }^{27}$.

\section{Corpus de obra conservada y documentada, y corpus de obra atribuida}

La única obra documentada y conservada de Huguet Barxa es la ya citada escultura lígnea de bulto redondo de Santa Práxedes (1458-1460) que en origen formaba parte de un retablo mixto (fig. 1 ${ }^{28}$. La pintura fue a cargo de Rafel Mòger, uno de los pintores mallorquines más deman-

${ }^{20}$ Item doní a mestra Huguet per hun jorn per adobar l'àngell e l'autre peu qui està denant l'altar major doni-li sis sous... $6 \mathrm{~s}$. y también Item doni al dit mestra per adobar lo dit àngell hun pern e claus e mastech e aygua cuyta... 3 s. (SASTRE MOlL, 2007: 576).

${ }^{21}$ En alguna ocasión le compró material pétreo (ACM, Libro de Fábrica 1729, f. 41) y años más tarde, como ya se ha indicado, esculpiría una gárgola (véase nota 18).

22 LlOMPART, 1998-1999: 53.

23 Piferrer y QuAdrado, 1969: 346-347.

${ }^{24}$ En cuanto al conjunto de ángeles actualmente presentes en el presbiterio de la catedral de Palma de Mallorca, Joana Maria Palou considera que los dos que flanquean la cátedra episcopal son, como acabo de señalar, obra de Llorenç Tosquella, mientras que los otros cuatro que rodean el altar mayor datarían del segundo cuarto del siglo XV. Estos últimos serían obra de un autor anónimo, cuyo estilo se enmarcaría en la tendencia borgoñona (PALOU, 1998: 253-255).

25 Ejecutó la traza del retablo mayor de la iglesia parroquial de Porreres en 1453, del cual el Museo de Mallorca conserva la tabla central dedicada a los santos Juanes, pintada por Rafel Mòger (LlOMPART, 1977: 330, nota 10). Era habitual que determinados escultores se encargasen de tareas semejantes, puede citarse igualmente el caso de Pere Morey, quien ejecutó la traza de un retablo que pintó Pere Marçol para la parroquia de Llucmajor en 1387 (LLOMPART, 1977-1980 vol. 4: 78-80, doc. 126).

${ }^{26}$ ARM, Protocolo M-185, f. 13v (1459, enero, 26). LlOMPART, 1977: 329, nota 8.

${ }_{27}$ Con todo, cabe decir que para algunos autores, como el mismo Gabriel Llompart, la situación sería inversa a la aquí expuesta. Es decir, que aquello que implicaba la necesidad de acudir a diversos campos era, en realidad, una falta de especialización (LLOMPART, 1977: 332).

28 Aguiló, 1905-1907: 29-30. Los datos -que según Aguiló se encontraban en un libro que fue a parar a sus manos (“á mis manos venido á parar un libro”) escrito por el mismo Antoni Busquets, beneficiado de la capilla de Santa Ana 


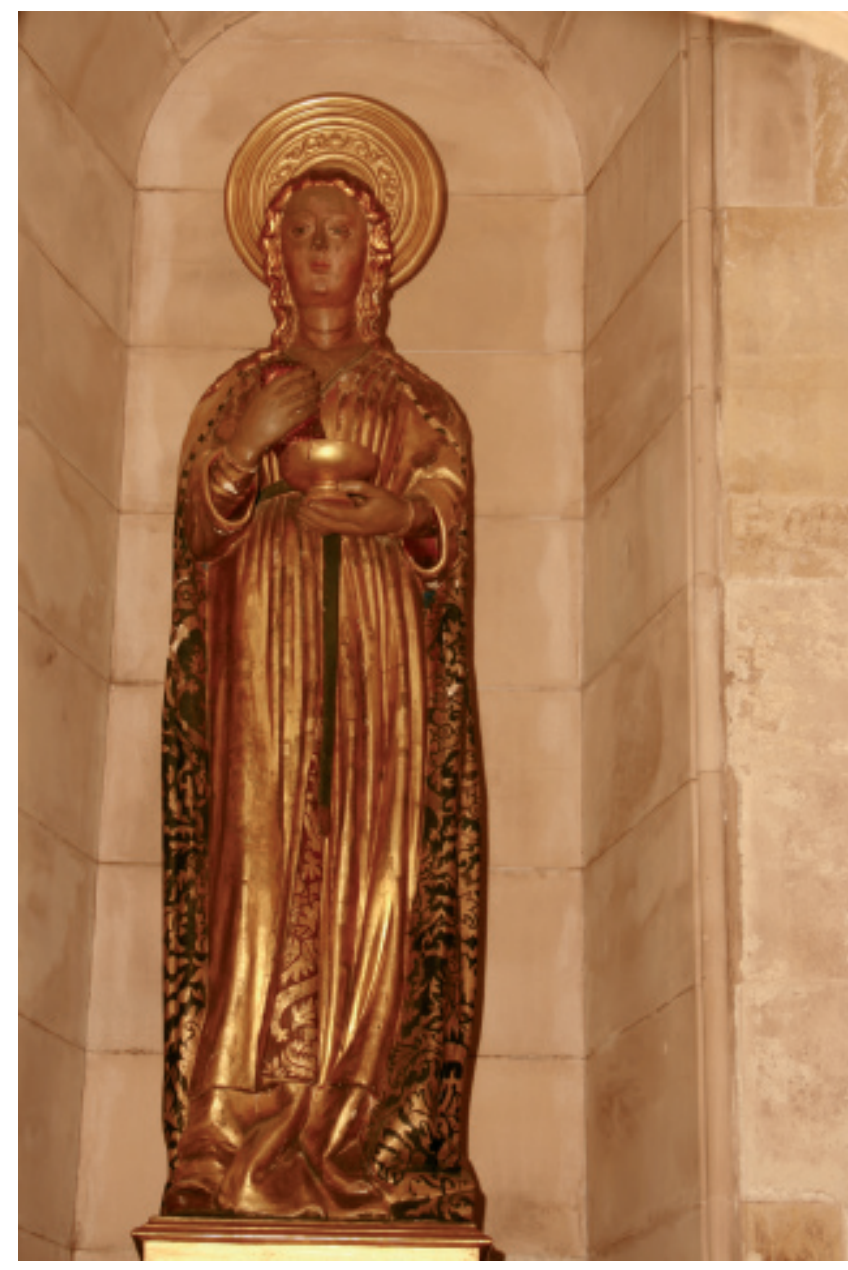

Fig. 1. Santa Práxedes (Capilla de Santa Práxedes, Palacio de la Almudaina, Palma de Mallorca). dados en aquellas fechas ${ }^{29}$, mientras que a Barxa se le encargó la imagen de la titular y -por interpretación documental-, la estructura, u obra de madera, del retablo ${ }^{30}$. Dicho retablo, que en origen fue concebido para ubicarse en una capilla lateral de la iglesia palatina de Santa Ana de la Almudaina, a principios del siglo XX fue trasladado al altar mayor, a excepción de la imagen escultórica que permaneció en la capilla para la cual fue concebida.

Esta obra ha permitido conocer su estilo y ha constituido el medio por el cual algunos autores le han atribuido determinadas piezas que restaban en el anonimato. Entre ellas cabe citar el retablo pétreo de la Passio Imaginis, custodiado en el santuario de San Salvador en Felanitx (Mallorca) ${ }^{31}$ y el grupo de la Lamentación, conservado en el Museo Diocesano de Mallorca ${ }^{32}$. Sin embargo, y pese a que tradicionalmente éstas atribuciones se han venido considerando como válidas, hay autores, como Francesca Español, que discrepan. Español señala que su confrontación con la escultura de Santa Práxedes, en especial por lo que respecta al tratamiento plástico de las telas, revela que no tienen nada en común ${ }^{33}$. En relación

de la Almudaina en los años en que se realizaron los pagos de la mencionada escultura-, aparecieron publicados por primera vez por el mismo Aguiló en Calendario para las Islas Baleares correspondiente al año 1895 [Almanaque de las Islas Baleares y anuarios de El Diario de Palma], 1894, pp. 35-38. El autor, en la publicación de 1905-1907 indica que los reproduce para evitar que se traspapelen. La localización del documento original ha sido inviable debido a que no cita la referencia. Al ser imposible consultar el libro de cual habla Aguiló, se ha acudido a documentación complementaria para intentar encontrar alguna referencia sobre los pagos por el retablo y la escultura. En concreto, y debido a que se trata de una obra que estuvo destinada a un espacio regio, se han consultado los libros de "Dades" de la serie Reial Patrimoni del Archivo del Reino de Mallorca. Desafortunadamente, no se han encontrado noticias algunas al respecto.

29 SABATER, 2002: 247-268.

${ }^{30}$ Item V albarans [...] tots per mestre Huguet Barxa smeginayre per fer la ymage e retaule de fusta per Sta. Praxedis [...]: Aguiló, 1905-1907: 30. SABATER, 2002: 252.

31 LLOMPART, 1977: 328-335.

32 Llompart y Palou, 1988: 128. Manote, 1998: 259-261.

33 ESPAÑOL, 2001: 316.

Arch. esp. arte, LXXXVII, 347, JULIO-SEPTIEMBRE 2014, 209-226

ISSN: 0004-0428, eISSN: 1988-8511, doi: 10.3989/aearte.2014.14 
a este presupuesto cabe decir que, en efecto, se aprecian ciertas divergencias entre ambas obras. Por ejemplo, la escultura de Santa Práxedes no es tan volumétrica como las del retablo de Felanitx pero sí presenta un tratamiento de los pliegues más rítmico que el de aquellas, en especial por lo que respecta a la túnica, al haberse trabajado éstos de forma paralela.

Por lo que respecta al retablo de la Passio Imaginis, cabe señalar que recientemente ha sido objeto de estudio por parte de Carlos Espí, quien a su vez lo ha atribuido a Guillem Sagrera ${ }^{34}$. Ello en base a las similitudes estilísticas presentes entre éste y las esculturas de la capilla de San Francisco (antes de la Pasión) de la iglesia parroquial de Felanitx, la cual ha sido identificada por buena parte de la crítica con la que el presbítero Jordi Sabet encargó a Guillem Sagrera en $1442^{35}$. Sea como sea, no es mi intención establecer la autoría de la capilla ni de las esculturas que la decoran ${ }^{36}$. Tampoco pretendo llevar a cabo un análisis exhaustivo sobre su supuesta -discutiblesimilitud con el retablo. No obstante, y en relación a la atribución tanto a Huguet Barxa como a Guillem Sagrera, sí quisiera hacer notar un documento datado el 9 de septiembre de 1450. En él consta que el presbítero Jordi Sabet, beneficiado de la iglesia de Felanitx, y Manuel Gonsalbo, platero, dieron potestad al mercader Just Morosino, -quien debía ir al condado de Flandes-, para que mandase realizar un retablo de la Pasión por un precio que no sobrepasase las 150 libras mallorquinas ${ }^{37}$. Considero que debería contemplarse la posibilidad que dicho documento haga referencia al retablo de la Passio Imaginis ${ }^{38}$. Ello explicaría, entre otras cosas, el carácter flamenquizante de la obra. Sin embargo, resultan evidentes las diferencias estilísticas entre los distintos paneles que lo configuran. En concreto en el panel superior central y en la predela, donde, en comparación con el resto de paneles, se percibe no sólo un tratamiento diverso de las figuras sino también en el motivo que decora los extremos superiores (fig. 2). Sí debo decir que en las figuras de los apóstoles de la predela, los "ecos" del estilo sagreriano se hacen presentes; sobre todo en los rostros, los cuales se asemejan a aquellos de los Evangelistas que se conservan en el Museo Diocesano de Mallorca ${ }^{39}$. Por lo tanto y atendiendo a ambos presupuestos, es decir, al documento antes citado y a las diferencias entre los paneles, pudiera darse el caso que el retablo de la Passio Imaginis fuese el resultado de un híbrido entre piezas importadas y otras realizadas en el contexto local. Hay constancia de que en ocasiones los retablos armonizaban elementos importados con otros ejecutadas en el lugar de destino ${ }^{40}$. Así pues, cabría la posibilidad que el retablo de Felanitx fuese el producto del montaje de paneles traídos desde el condado de Flandes, tal y como se había solicitado al mercader Just Morosino, y otros realizados -quizá previamente a la fecha en que se encargó el retablo- por un artesano local. Este último conocedor del estilo de

34 Espí, 2009: 20-34

35 Rosselló Vaquer, 1975: 219.

${ }^{36}$ La problemática relacionada con esta capilla es compleja, sobre todo por lo que respecta a los restos escultóricos. Algunos autores, entre los que se cuentan Gabriel Llompart (Llompart, 1983: 411) y Marià Carbonell (CARBONELL BUADES, 2007-2008: 62-63), no aceptan la autoría de Sagrera.

37 Rosselló Vaquer, 1975: 165. Rosselló Vaquer, 1997: 143.

38 Carlos Espí tiene en cuenta este dato pero opina que no se trata del retablo de la Passio Imaginis sino de un posible retablo pictórico (Espí, 2009: 33, nota 54).

39 Al referirme a "ecos" sagrerianos no quiero decir ni mucho menos que piense que la obra sea de Guillem Sagrera. La calidad de la obra de Sagrera y de sus discípulos más aventajados supera con creces las esculturas del retablo de Felanitx. Además, debe tenerse en cuenta que en aquellas fechas tanto Guillem Sagrera como los miembros más destacados de su taller estaban inmersos en los trabajos de la Lonja y de la catedral, los cuales es poco probable que estuviesen dispuestos a posponer para empezar otro encargo. En todo caso se habría acudido al recurso de la subcontrata.

40 Es el caso de un retablo encargado el 1428 al pintor mallorquín Gabriel Mòger, en cuyo convenio se especifica que aquello que ha de realizar el artista debe armonizar con el bancal, que es obra de Flandes. Aunque el documento se ha interpretado en clave pictórica, Francesca Español considera que de éste se infiere que podría tratarse de una obra escultórica (ESPAÑOL, 2001: 296). 


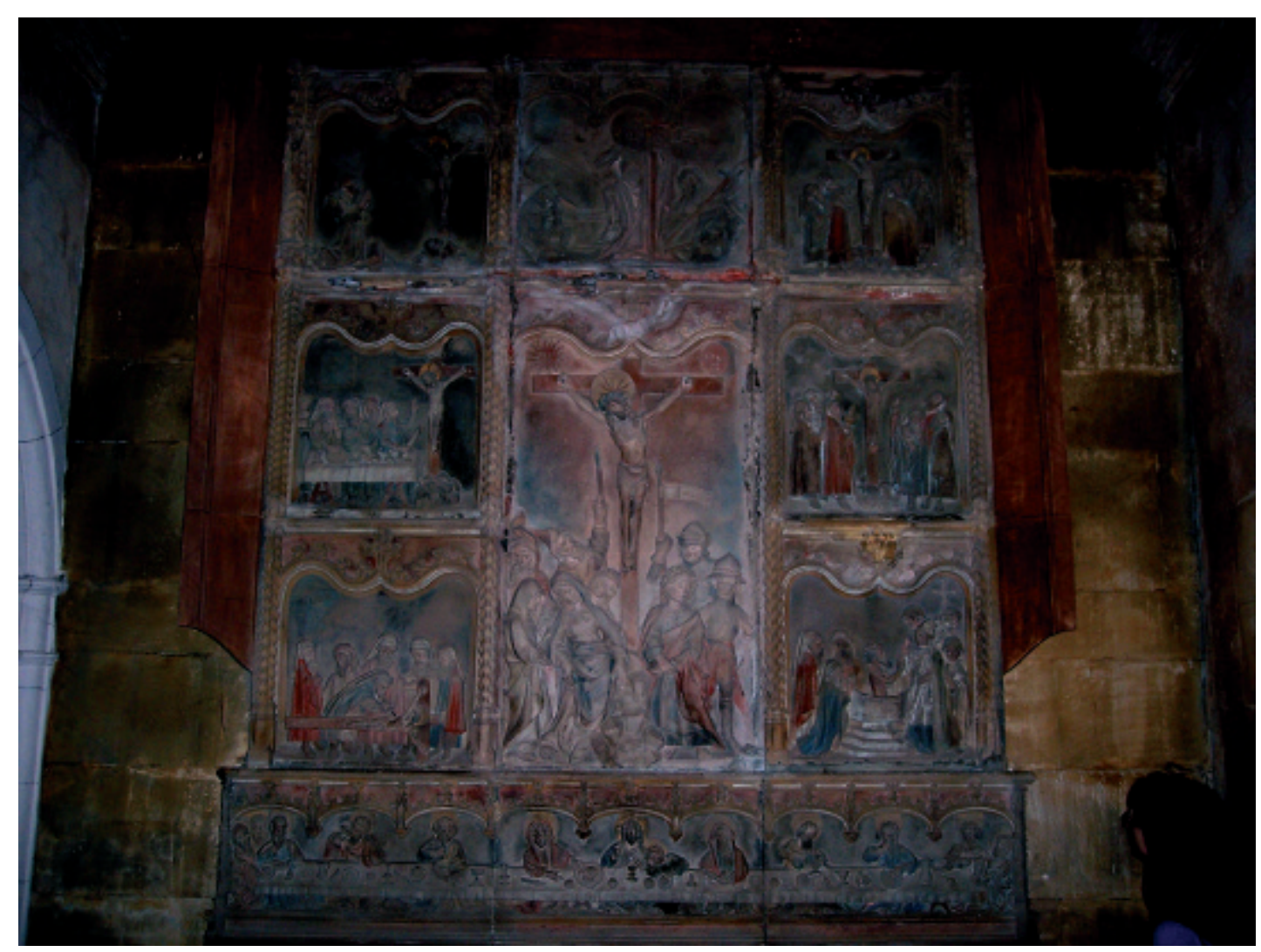

Fig. 2. Retablo de la Passio Imaginis (Santuario de San Salvador, Felanitx).

Guillem Sagrera pero carente de su talento y del de sus discípulos más aventajados. No obstante, se trata de una hipótesis hecha en base a parámetros estilísticos que precisaría de un análisis petrográfico para confirmar la diversa procedencia del tipo de piedra con la que se esculpieron los paneles ${ }^{41}$. En cualquier caso, lo que sí queda patente es la intervención de al menos dos manos en su ejecución.

Por lo que respecta a la atribución hecha a Huguet Barxa que, en realidad, es lo que aquí interesa, y a la luz de los presupuestos anteriores -tanto lo comentado sobre el origen del retablo como lo indicado sobre las diferencias de estilo entre el mismo y la única obra documentada de Barxa-, considero que debería reconsiderarse la atribución hecha en su día por Gabriel Llompart. A su juicio, ésta se basaba en la semejanza entre la cabeza de María Magdalena de la escena de la Crucifixión del panel central del retablo de Felanitx y la de Santa Práxedes ${ }^{42}$, pero no tenía en cuenta el resto de variables señaladas que permiten cuestionar, si no desestimar, dicha atribución.

${ }^{41}$ A día de hoy, las gestiones llevadas a cabo no han posibilitado la realización de dicho análisis.

42 LLOMPART, 1977: 334.

Arch. esp. arte, LXXXVII, 347, JULIO-SEPTIEMBRE 2014, 209-226

ISSN: 0004-0428, eISSN: 1988-8511, doi: 10.3989/aearte.2014.14 
En relación al grupo de la Lamentación, la premisa principal por la cual ha sido atribuido a Barxa es la similitud de sus figuras con las de la escena principal del retablo de la Passio Imaginis $^{43}$. Por lo tanto, si puede desestimarse la atribución a Barxa de este último también debería cuestionarse la de aquél. Además, al observar la factura de los ropajes, así como la gestualidad y el expresionismo de los personajes de la Lamentación, y se comparan con la Santa Práxedes se constatan las diferencias de ejecución, en el mismo sentido en que se habían señalado para el retablo de Felanitx.

\section{Nuevas propuestas de atribución}

Como se ha comentado en líneas precedentes, se da por sentado que Huguet Barxa participó en los trabajos de construcción de la Lonja. Atendiendo al hecho que se halla dentro del escaso número de artesanos de la piedra entre cuyas variadas denominaciones se encuentra la de ymaginaire, sin duda debió ejecutar algún trabajo escultórico.

En una obra de taller de la magnitud de la Lonja - de la cual desconocemos el nombre de buena parte de los artífices que intervinieron-, resulta difícil y arriesgado hacer propuestas de atribución. Aun así, considero que puede verse la mano de Huguet Barxa en dos claves de bóveda con iconografía angélica de la gran sala (fig. 3 y 4). Al no conservar documentos explícitos sobre el particular, el análisis estilístico se erige en la única vía para llevar a cabo dicha afirmación. Para ello el punto de partida es, de nuevo, la escultura de Santa Práxedes. No obstante, deberán tenerse en cuenta dos aspectos que pueden distorsionar la correcta apreciación. En primer lugar, que la comparativa se realiza entre obras ejecutadas con materiales diversos: la piedra para las claves de bóveda y la madera para la imagen hagiográfica. Las herramientas utilizadas en cada caso son diferentes y la respuesta de los materiales ante la persona que los trabaja también lo es; aspecto que repercute en el resultado final. En segundo lugar, las esculturas están recubiertas por una capa de policromía que, sobre todo en el caso de los ángeles, no parece ser original; hecho que dificulta captar lo genuino de la obra. Todo en conjunto podría inducir a error a la hora de atribuir una obra concreta a un autor determinado. Aun así, si se compara la Santa Práxedes (fig. 1) con los ángeles, en especial con la fig. 3, se observa que la configuración del rostro es muy similar. Los ojos caídos, con los párpados entrecerrados y el marcado mentón presentan suficientes semejanzas para aventurar una hipótesis de atribución a Barxa.

Por otro lado, pero también en relación con la familia Sagrera, tenemos documentada, en 1449, la intervención de Huguet Barxa en la capilla de Nuestra Señora de Gracia o de los Desamparados $^{44}$. En esa fecha, Miquel Sagrera -sobrino de Guillem Sagrera, quien dejó el proyecto en sus manos antes de marchar a Nápoles ${ }^{45}$ - le pagó 30 libras y 3 sueldos por la factura de unos trabajos, cuya naturaleza no se especifica. Con todo, y atendiendo que en dicho documento Barxa es calificado de asmaginayre, debemos suponer como más probable que la labor llevada a cabo consistió en algún trabajo de índole escultórica. Cabe señalar que el interior de la capilla de Nuestra Señora de Gracia ha experimentado toda una serie de reformas que han transformado de tal modo la arquitectura original que nada de lo medieval ha llegado hasta nuestros días. Sí conservamos, en cambio, algunos restos originales de la portada de acceso. Se trata de dos ángeles que presentan las mismas características que aquellos que rematan las tracerías de los ventanales de la Lonja y que, en este caso, se encuentran en el extremo del intradós del arco por el cual se

\footnotetext{
43 Manote, 1998: 259-261.

44 BarCeló y Llompart, 1998: 91, doc. 10. Se trata de una construcción de reducidas dimensiones que en origen fue la sede de la cofradía de los judíos conversos y que en la actualidad está adosada a la iglesia del Socorro.

45 Llompart, 1973: 100-101, doc. 9.
} 


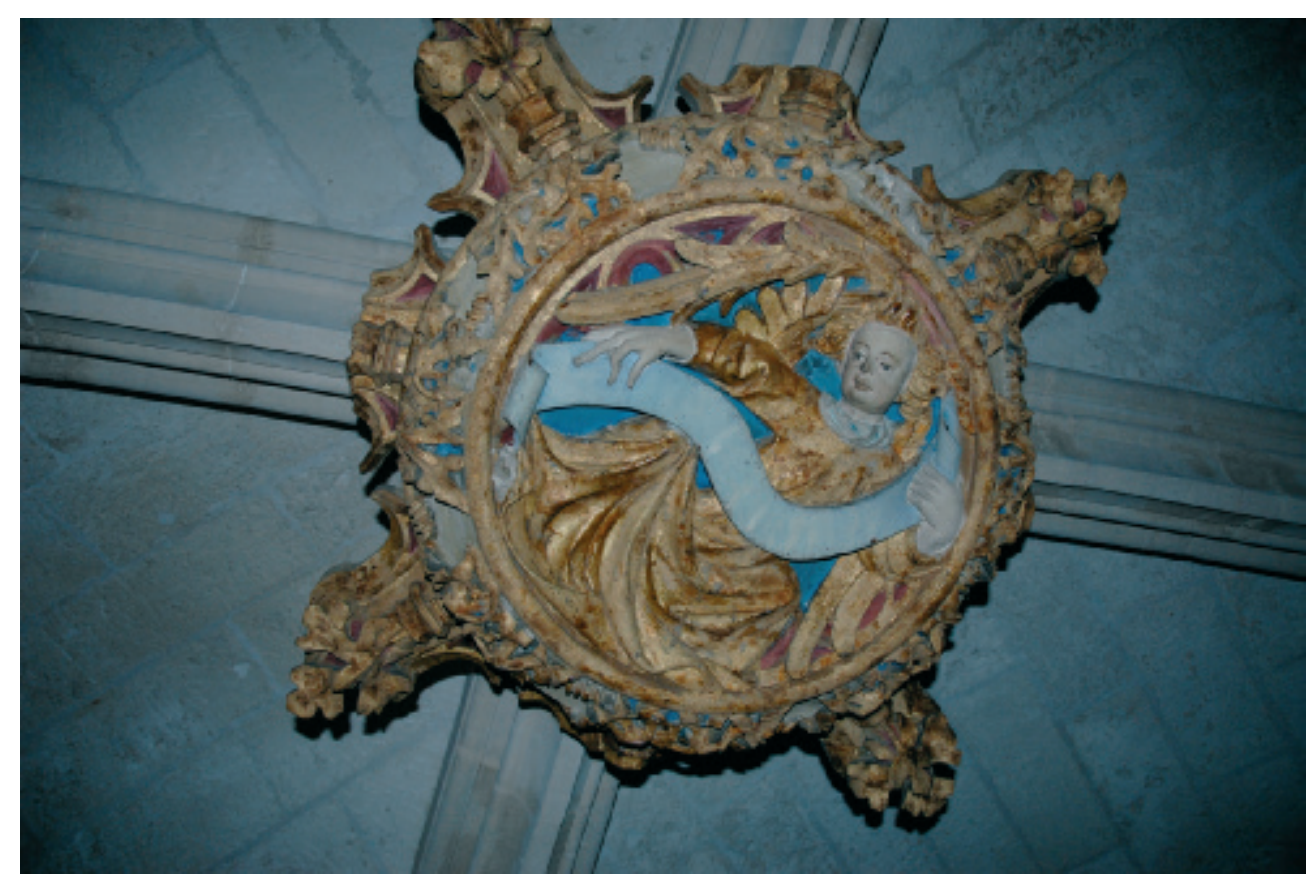

Fig. 3. Ángel con filacteria (Clave de bóveda de la Lonja, Palma de Mallorca).

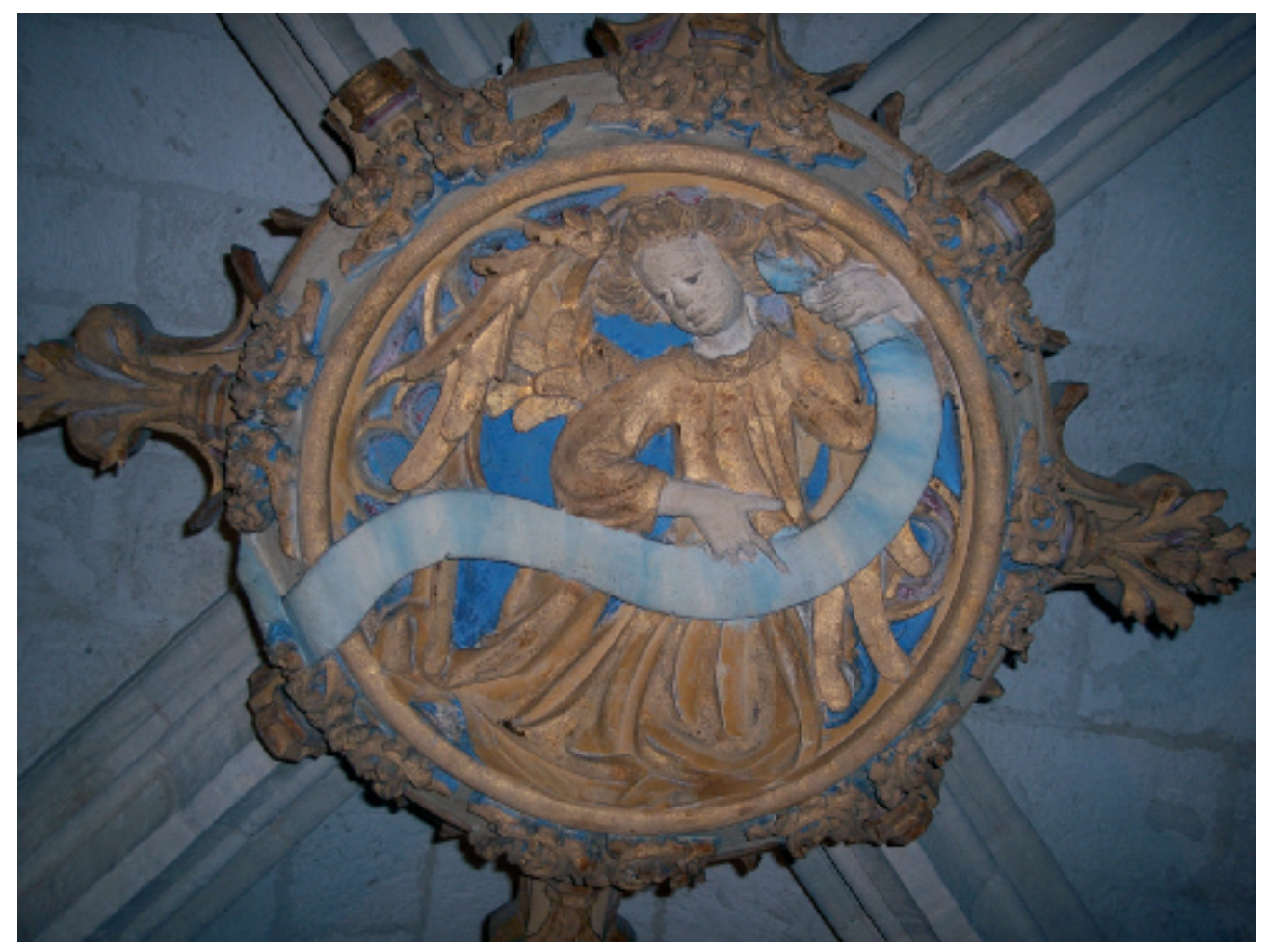

Fig. 4. Ángel con filacteria (Clave de bóveda de la Lonja, Palma de Mallorca).

Arch. esp. arte, LXXXVII, 347, JULIO-SEPTIEMBRE 2014, 209-226

ISSN: 0004-0428, eISSN: 1988-8511, doi: 10.3989/aearte.2014.14 
accede a la construcción. Aunque cabría la posibilidad que los hubiese ejecutado Huguet Barxa, en realidad este tipo de angelillos fueron un motivo asaz recurrente y estereotipado del taller sagreriano para aventurarse a emitir juicio alguno sobre su autoría.

Volviendo a la imagen de Santa Práxedes y al espacio para el cual fue concebida -la capilla homónima de la iglesia palatina de Santa Ana de la Almudaina-, quisiera incidir sobre un aspecto que hasta ahora no se había tenido en consideración: la posible participación de Huguet Barxa en la escultura arquitectónica de dicha capilla. Aunque se dice que Alfonso el Magnánimo fundó la capilla en $1432^{46}$, parece ser que su factura sería posterior, ya que de algunas referencias documentales se infiere que se intervino hasta poco antes de $1458^{47}$. Desconocemos quien fue el artífice (o los artífices) de la arquitectura, aun así, y atendiendo que se trata de una obra de promoción real, lo más probable es que de su ejecución se encargase el maestro de obras del rey o bien miembros integrantes de su taller. Entre 1453 y 1475 quien ostentaba el título de maestro de las obras del rey era Cristòfol Vilasclar ${ }^{48}$, miembro de una destacada familia de lapiscidae mallorquines ${ }^{49}$. Entonces, ¿cuál es el papel de Huguet Barxa? Pues bien, debemos tener en cuenta, como ya se ha comentado con anterioridad, que entre 1458 y 1460 se le expiden documentos de pago por la escultura y el retablo de la capilla de Santa Práxedes ${ }^{50}$. Tomando como punto de partida esta vinculación y comparando la escultura lígnea con otros elementos figurativos de dicha capilla, considero plausible la intervención de Barxa en alguna pieza de escultura arquitectónica; en concreto en la clave de bóveda donde se representa Santa Bárbara (fig. 5). Si bien es cierto que en ocasiones las claves de bóveda son obra seriada de taller y pese a ciertas diferencias entre ésta y la escultura de Santa Práxedes (diversidad de materiales, distinto canon, ejecución dispar en algunos detalles como las manos), ambas figuras presentan paralelismos, sobre todo en la factura de las telas. Así pues, vemos como las túnicas se han trabajado del mismo modo a partir de líneas verticales paralelas que caen a los pies formando pliegues. Además, el tipo de manto es el mismo, puesto que no se recurre al tradicional recurso de la fíbula sino que éste descansa libre sobre los hombros.

El hecho de sugerir la intervención de Barxa en una parte del programa escultórico de la capilla de Santa Práxedes no invalida la participación en la misma de Cristòfol Vilasclar -a quien, en calidad de maestro mayor de las obras del rey, podría atribuírsele el diseño del conjunto- y, quizás, otros miembros de su taller. En este sentido, podría justificarse la menor calidad de ejecución de determinados elementos de la escultura de Santa Bárbara, como por ejemplo las manos, por ser, precisamente, una obra de taller donde intervinieron varios artífices. Se precisa señalar que, al margen de ciertos motivos de marginalia de carácter zoomórfico y/o híbrido, la clave de bóveda constituye la única escultura figurativa del conjunto. Téngase en cuenta que Huguet Barxa es uno de los pocos artífices documentados en Mallorca como ymaginaire. Ello, junto con su documentada vinculación con la capilla de Santa Práxedes y las semejanzas entre ambas esculturas, se erige en indicativo suficiente para tener en cuenta la intervención de Barxa en dicha clave de bóveda.

46 Conrado de Villalonga, 1992: 99.

47 Aguiló, 1905-1907: 29-30. YSASI, 1998: 30. Llompart, 1999: 53, doc. 106. En el documento publicado por Llompart y datado en marzo de 1459 ya se deduce que la capilla estaba construida.

${ }^{48} \mathrm{La}$ documentación indica que ostentó el cargo primero en nombre de Guillem Sagrera, quien, como se sabe, desde 1447 hasta 1454 residió en Nápoles (ARM, Real Patrimonio, 3545, f. 15) y tras su muerte, en 1454, en nombre de su hijo Jaume Sagrera, quien igualmente residía en la ciudad partenopea (ARM, Real Patrimonio 3550, f. 15v-Real Patrimoni, 3589, f. 15).

49 BARCELÓ, 1993: 127-140.

50 El contenido textual de los documentos lo transcribe Estanislao Aguiló de un original actualmente ilocalizable (véase nota 28). 


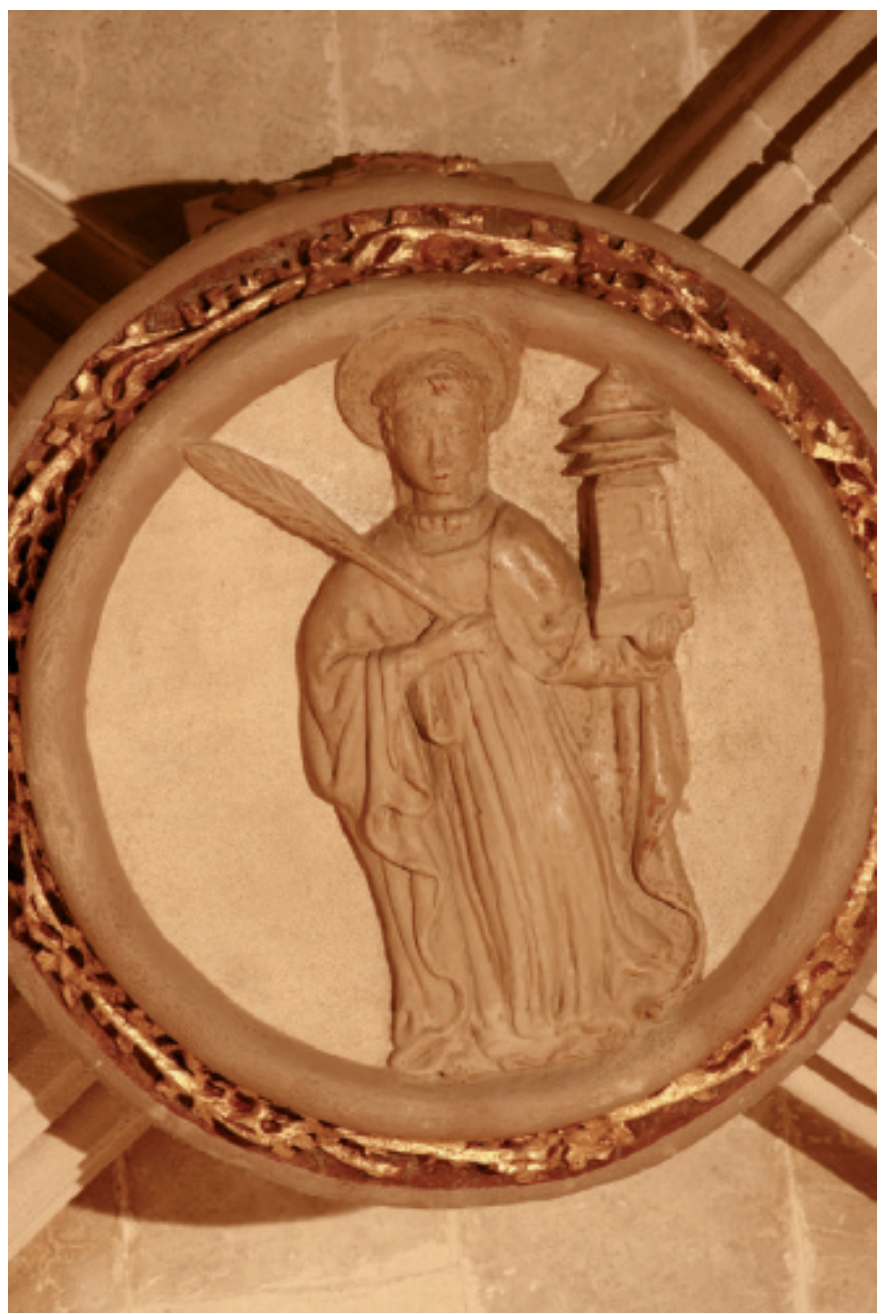

Fig. 5. Santa Bárbara (Clave de bóveda de la capilla de Santa Práxedes, Palacio de la Almudaina, Palma de Mallorca).

En relación con la imagen de Santa Bárbara que se acaba de comentar, quisiera hacer notar las semejanzas que ésta presenta con dos relieves que decoran un medallón esculturado de la sillería del coro del convento de San Francisco de Palma. Dicha obra fue encargada al escultor catalán Macià Bonafè en 1447 (13 de octubre $)^{51}$. Aunque en el contrato se estipulaba que la obra debería finalizarse en dos años y medio, se sabe que ésta se retrasó considerablemente, puesto que Bonafè recibió el último pago el día 11 de octubre de 1455. También sabemos, gracias al documento contractual, que para llevar a cabo dicha obra se sirvió de colaboradores, hecho habitual en artesanos que, como él, compaginaban y trabajaban de forma simultánea en encargos diversos. Concretamente, contó con dos integrantes del taller que regentaba en Barcelona, quienes se trasladaron a Mallorca para tal cometido. Con todo, un encargo de similares características requeriría de un mayor número de efectivos, más teniendo en cuenta que el maestro no le dedicó su exclusividad - en contra de lo que se estipulaba en el contrato-, sino que también dirigió otros proyectos en la Península ${ }^{52}$. Por tanto, lo más probable es que se valiese de efectivos locales para llevar a cabo la obra. En este sentido, en la documentación aparecen los nombres de carpinteros, como Jaume Bertrán y Luís de Lezda (este último extranjero) y de picapedreros, como Joan Vilasclar y Bernat Truyol, quienes comparecieron sólo en calidad de testigos. Pese a que en dicha nómina no figura Huguet Barxa, debería tenerse en cuenta que, entre los artesanos documentados en Mallorca por aquellas fechas, él era uno de los más destacados por lo que respecta a la actividad escultórica. Al menos es lo que se desprende de la documentación exhumada hasta la fecha. Por

51 LlOMPART, 1973: 110-113. Sobre este artista véase también TerÉs TomÀs, 1986: 65-85. LóPez IBORRA, 2007a: 190-199.

52 Terés TomÀs, 1986: 65-85. López Iborra, 2007b: 30. Pons Cortés y GonZÁlez Ansorena, 2009: 469-471.

Arch. esp. arte, LXXXVII, 347, JULIO-SEPTIEMBRE 2014, 209-226

ISSN: 0004-0428, eISSN: 1988-8511, doi: 10.3989/aearte.2014.14 

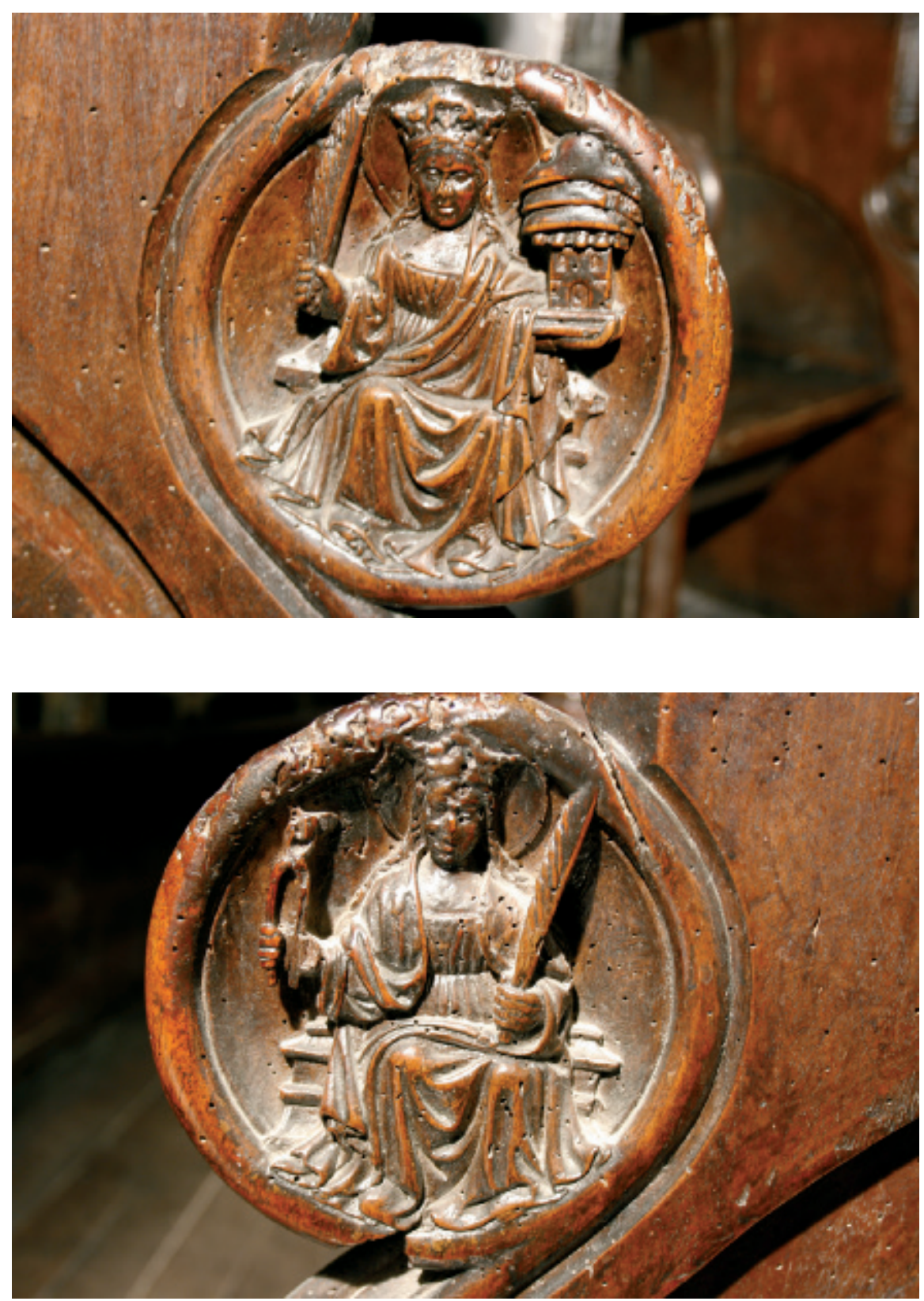

Fig. 6. Santa Bárbara

(Medallón, sillería del coro del convento de San Francisco, Palma de Mallorca).
Fig. 7. Santa Apolonia (o Santa Águeda) (Medallón, sillería del coro del convento de San Francisco, Palma de Mallorca).

tanto, no resulta descabellado pensar que pudo haber tomado parte, aunque fuese sólo de forma puntual, en uno de los trabajos lígneos más importantes de los ejecutados en la isla a mediados del siglo XV. Además, si nos fijamos en los relieves escultóricos que decoran el medallón de un sitial donde se han representado -en ambas caras- Santa Bárbara (fig. 6) y Santa Apolonia (o Santa Águeda, fig. 7) veremos no sólo las similitudes existentes con la clave de bóveda de la capilla sino también con la escultura de Santa Práxedes. En relación a la clave, éstas de nuevo 
se aprecian en el tipo de indumentaria, en la forma de trabajar los pliegues y, en especial, en la manera en que la túnica descansa sobre el brazo; también en los rostros suaves y redondeados o en el cabello, que apenas se desmarca del contorno del rostro. Un detalle significativo lo constituye el atributo de Santa Bárbara, cuya singularidad radica en la forma en que se ha resuelto la torre, rematada por un elemento triple, idéntica en ambas representaciones. Por lo que respecta a la escultura de Santa Práxedes, si comparamos la ejecución de su mano derecha con la izquierda de Santa Apolonia, observaremos semejante calidad de ejecución, particularidad que, en cambio, no se apreciaba en la clave de bóveda, posiblemente por ser, tal y como se ha indicado en líneas precedentes, el resultado de un trabajo de taller. Las similitudes de las figuras del medallón con la obra documentada de Barxa no se aprecian sólo en la ejecución de las manos; también se perciben en otros detalles como la factura y disposición del cabello, trabajado a partir de discretas ondulaciones que remarcan el contorno del rostro y descansan sobre ambos hombros en finas guedejas, además de las ya comentadas con los pliegues de la túnica. Así pues, a la luz de lo que se acaba de comentar, considero que todas estas obras pueden ser atribuidas a la misma mano.

Al margen de las piezas hasta ahora analizadas, quisiera poner el acento en dos esculturas muy interesantes y de notable calidad pero poco conocidas. Me refiero a las ménsulas que sostienen el arco diafragma de la sala capitular del antiguo convento de Santa Margarita de Palma. En una de ellas se representa la Virgen con el Niño acompañada de ángeles músicos (fig. 8) y en la otra la santa titular del cenobio (fig. 9). Ni el espacio ni las ménsulas están documentados, hecho que ha provocado que se ofrezcan diversas dataciones. Algunos autores afirman, sin justificarlo, que la sala capitular data del siglo $\mathrm{XIV}^{53} \mathrm{y}$, en consecuencia, otros datan las ménsulas en esa cronología ${ }^{54}$. Tal vez, el motivo por el cual se ofrece esa datación sea por la reforma que llevó a cabo durante su priorato sor Catalina Torrella (1341-1374), que afectó al ábside y a la apertura de algunas capillas laterales ${ }^{55}$. Pese a que ningún dato explícito se refiere a la sala capitular, la actividad constructiva emprendida por aquellas fechas podría haber inducido a los investigadores a pensar que se hubiese intervenido, igualmente, en dicho espacio. Sin embargo, debemos tener en cuenta que a mediados del siglo XV también se emprendió una notable política de patronazgo artístico por la cual la entonces vigente priora encargó obras tales como el antiguo retablo mayor de la iglesia ${ }^{56}$. Si analizamos las esculturas, veremos que su estilo se acerca más al de mediados del XV en adelante que no al del XIV. Al respecto, el tipo de indumentaria de la Virgen con el escote recto y el manto sin fíbula proliferó durante el siglo $\mathrm{XV}$, pese a que ya en el siglo XIV podamos encontrar algún ejemplo ${ }^{57}$. Del mismo modo, la tipología del rostro, de pómulos redondeados, la nariz recta y ligeramente alargada, la barbilla puntiaguda, la frente ancha y despejada, enmarcada por el cabello que, partido por la mitad, cae a ambos lados de la cara; todo ello remite, aunque sea vagamente, a los arquetipos femeninos de los primitivos flamencos ${ }^{58}$.

Es precisamente a mediados del siglo XV cuando Huguet Barxa está en plena madurez profesional y cuando su estilo ya habría evolucionado desde los días en que trabajó en la Lonja. Debe tenerse en cuenta, también, tal y como se ha comentado en líneas precedentes, que Barxa

\footnotetext{
53 Alomar Esteve y Alomar Canyelles, 1994: 31-32. Palou, 1999: 391.

54 CARBOnell, 2004: 27.

55 PAscual y LlabrÉs, 1992: 32.

56 Se trata del retablo documentado entre 1455-1456, obra del pintor Joan Rosat, del cual se conserva la predela. Actualmente fragmentada, una parte se custodia en el Museo de Mallorca y la otra en la sala capitular del convento de la Concepción de Palma. Llompart, 1988: 45-52. SABATER, 2002: 227, 289-294.

57 Bernís, 1970: Láminas I y VIII. SigüEnZA PERLADA, 2000: 141.

58 En el arte mallorquín este modelo lo volveremos a encontrar ya en unas fechas más tardías en algunas obras del pintor Pere Terrenchs.
}

Arch. esp. arte, LXXXVII, 347, JULIO-SEPTIEMBRE 2014, 209-226

ISSN: 0004-0428, eISSN: 1988-8511, doi: 10.3989/aearte.2014.14 


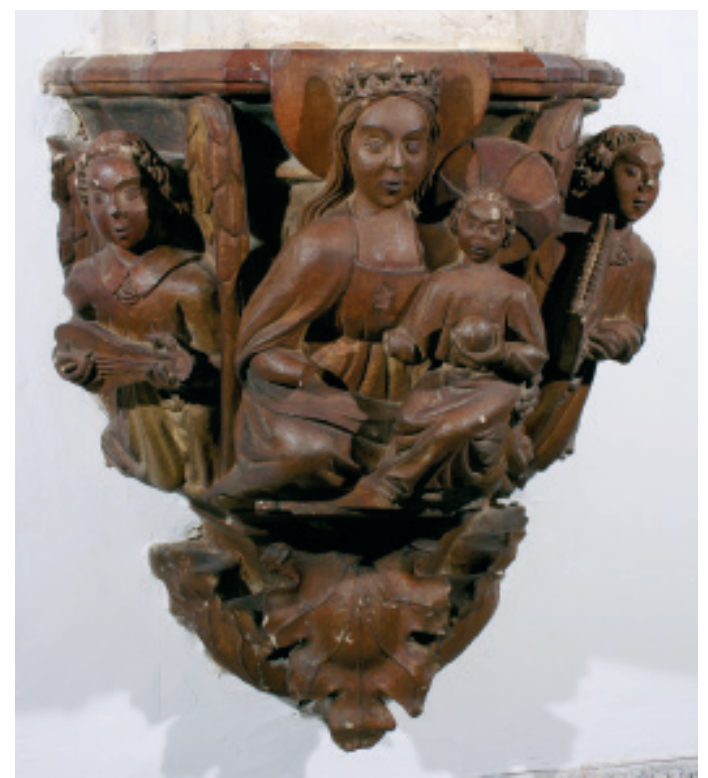

Fig. 8. Virgen con el Niño y ángeles músicos (ménsula de la sala capitular del antiguo convento de Santa Margarita, Palma de Mallorca).

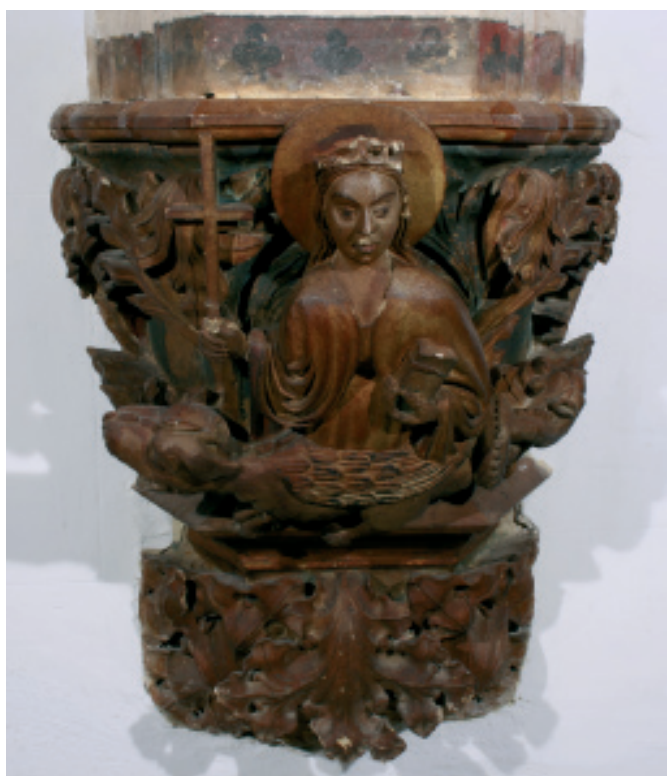

Fig. 9. Santa Margarita (ménsula de la sala capitular del antiguo convento de Santa Margarita, Palma de Mallorca).

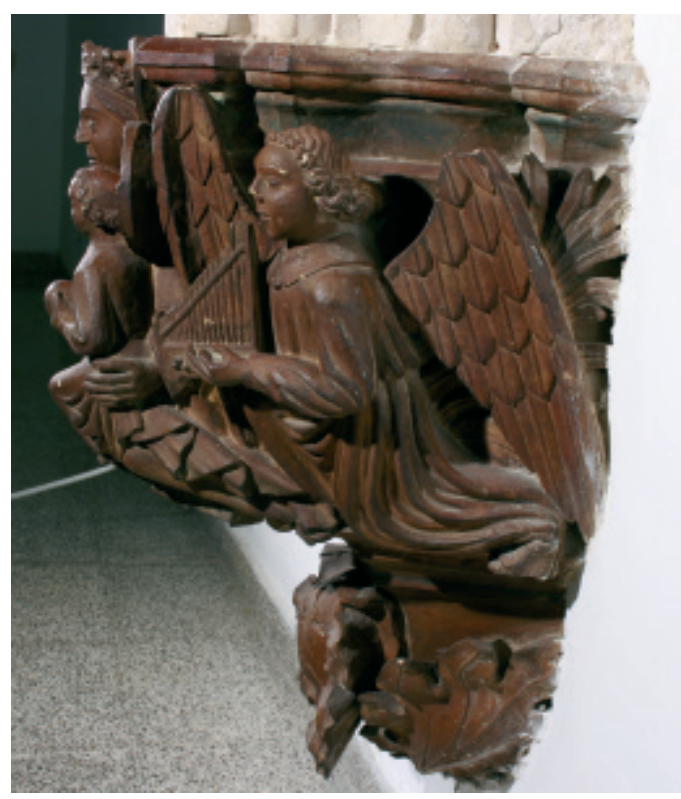

Fig. 10. Ángel músico (detalle de la fig. 8).

Arch. esp. arte, LXXXVII, 347, JULIO-SEPTIEMBRE 2014, 209-226 ISSN: 0004-0428, eISSN: 1988-8511, doi: 10.3989/aearte.2014.14 
fue uno de los escultores más demandados del momento y uno de los que tienen más obra escultórica documentada. Ello por sí solo no justifica que se le puedan atribuir las ménsulas de la sala capitular del convento de Santa Margarita. No obstante, si nos fijamos ya no sólo en el rostro que presenta similitudes con el de la Santa Práxedes, por el tipo de nariz recta, los párpados muy marcados o el mentón puntiagudo-, sino sobre todo en el modo en que se ha resuelto la indumentaria -la cual no adopta los típicos pliegues quebrados-, veremos que ésta ha sido trabajada del mismo modo que el resto de obras que aquí se le atribuyen. Así pues, el escote y el entalle de la Virgen es el mismo que el de la Santa Bárbara del medallón del coro de San Francisco; el manto de Santa Margarita presenta una disposición y forma unos pliegues semejantes al de Santa Apolonia; asimismo, los pliegues de la indumentaria de los ángeles (fig. 10) siguen el mismo patrón que los de la túnica de Santa Práxedes (fig. 1) y los de Santa Bárbara (fig. 5) -gruesos plisados dispuestos paralelamente y que caen en vertical, sin ampulosidad y con poca volumetría. Resulta igualmente notable la correcta ejecución de las manos y las notables similitudes en su disposición y en la forma en que sujetan los atributos. Todo ello en conjunto, es lo que me lleva a pensar en Huguet Barxa como posible artífice de las ménsulas.

Al margen de la producción escultórica conservada, ya sea documentada o bien atribuida, quisiera hacer un breve comentario sobre una obra actualmente desaparecida, relacionada con otro cenobio femenino que, a la luz de la documentación existente, podemos vincular con el artífice que nos ocupa. Me estoy refiriendo a la antigua iglesia del convento de Santa Isabel, cuya construcción sabemos fue a cargo de Huguet Barxa gracias al documento hallado por Gabriel Llompart ${ }^{59}$. Pese a que en la actualidad no se conserva ningún resto físico de la primitiva iglesia, nos podemos hacer una idea de su estructura original gracias a fuentes gráficas coetáneas. Este aspecto lo evidenció Tina Sabater en la ponencia que presentó en el congreso sobre portadas góticas en la Corona de Aragón (Barcelona, diciembre de 2012). Así pues, en la tabla conservada del antiguo retablo mayor del convento y en una miniatura del libro de las Constituciones, vemos representado San Jerónimo con la maqueta de la iglesia en sus manos ${ }^{60}$. Al margen de las licencias que los pintores se tomaban a la hora de representar elementos arquitectónicos, en este caso en particular Sabater destacó las similitudes existentes entre ambas arquitecturas, sobre todo por lo que respecta a la ejecución de la portada. Significativamente, ésta presenta rasgos propios del gótico meridional, que pueden observarse tanto en iglesias del contexto isleño como del catalano-aragonés: portada sencilla, con tímpano y parteluz, delimitada por dos agujas y configurada por un arco ojival recorrido por una fronda de cardinas y rematado por un florón. Por lo tanto, es más que probable que el pintor se inspirase en el modelo original. Como detalle relevante, y que diferencia esta portada de otras como las de la iglesia de San Nicolás o el Portal de la Almoina de la catedral, Sabater destacó la presencia de esculturas en el tímpano. En efecto, al fijarnos en la maqueta representada en la pintura sobre tabla, podemos intuir la presencia de un conjunto escultórico. Es más, si agudizamos la vista, podemos intuir la representación de lo que parece ser una Virgen con el Niño flanqueada por ángeles (a semejanza del tímpano de la iglesia de San Miguel de la misma ciudad). Pese a que en el contrato original para la ejecución de la iglesia no se detalle nada sobre el programa escultórico, ¿sería plausible que hubiese sido Barxa el autor material de esas esculturas? Soy consciente que resulta algo temerario sugerir esta cuestión sin el apoyo de otras fuentes, no obstante considero que se trata de un aspecto que debe plantearse al tratar sobre la producción de este escultor.

59 LlOMPART, 1988: 48-49.

60 La pintura sobre tabla (1504-1508) fue pintada por Pere Terrenchs y la miniatura (1507) se atribuye a su taller, quizás obra de Joan Català. SABATER, 2002: 351-352, 356, 430, 433.

Arch. esp. arte, LXXXVII, 347, JULIO-SEPTIEMBRE 2014, 209-226

ISSN: 0004-0428, eISSN: 1988-8511, doi: 10.3989/aearte.2014.14 


\section{A modo de conclusión}

Para concluir el análisis sobre la figura y la actividad escultórica de Huguet Barxa, decir que, si bien es el ymaginaire de quien se ha recopilado mayor información, se trata de un personaje todavía enigmático, puesto que en realidad desconocemos su verdadera nacionalidad y sus orígenes formativos.

Pese a estar vinculado al taller de los Sagrera ${ }^{61}$, su estilo no refleja los típicos estilemas sagrerianos que caracterizaron buena parte de la producción escultórica mallorquina del siglo XV. La excepción a este presupuesto serían las claves de bóveda con iconografía angélica de la Lonja (figs. 3 y 4), las cuales - por formar parte de un programa concreto en el cual debían seguirse unas directrices predeterminadas- presentan unidad de ejecución, tanto en la composición de los volúmenes como en ciertos detalles secundarios, como las alas o la filacteria, con otras esculturas del mismo edificio. Sin embargo, el patrón escogido para la representación del cabello huye de los típicos rizos de las esculturas sagrerianas. Así pues, a diferencia del resto de figuras angélicas, vemos como en las que aquí se atribuyen a Barxa se ha optado por otra solución. Si bien es cierto que en estos dos casos en concreto el cabello se ha trabajado con una cierta volumetría -a diferencia de su única obra documentada y conservada y de otras esculturas que también se le han atribuido-, no lo es menos que no alcanza la exuberancia del resto de ejemplares presentes en el edificio. Asimismo, por lo que respecta a la configuración de los rostros de esculturas como Santa Práxedes o las ménsulas del convento de Santa Margarita su estilo remite a modelos flamenquizantes. Ello podría deberse a una actitud más abierta a la moda de mediados del siglo XV, que poco a poco se iba imponiendo en la plástica de los territorios de la Corona de Aragón, a diferencia de otros artífices que optaron por la perpetuación de modelos sagrerianos.

En el caso de Barxa, a diferencia de lo que ocurre con otros maestros de la época, como el mismo Sagrera, parece ser que no formó escuela. Que sepamos, no se le conoce ningún discípulo directo y parece ser que su estilo tampoco tuvo mucha proyección, si lo comparamos de nuevo con el de Sagrera. Es cierto que tenía un hijo, pero por el momento los datos que sobre él se han hallado no son suficientemente indicativos para sostener que siguió los pasos de su progenitor $^{62}$. Aun así, se puede afirmar que Huguet Barxa fue un artesano destacado del panorama local, no sólo por mantener contactos con la familia más influyente de la isla en materia artística sino también porque su trayectoria profesional, que podemos entrever a través de la documentación conservada y de las obras adscritas a su catálogo, lo avala como uno de los lapiscidae-ymaginaires más destacados de Mallorca durante la Baja Edad Media.

Con todo, sigue siendo una figura un tanto controvertida porque el corpus de obra que se le atribuye es dispar, de aquí las discrepancias entre los investigadores. En el presente trabajo se ha optado por dar un nuevo enfoque a su producción escultórica, con el objetivo de abrir otras vías de investigación y de ofrecer un poco más de luz sobre la figura de este escultor bajomedieval.

${ }^{61}$ Primero con Guillem Sagrera, supuestamente en el marco de la catedral (1427) y en el de la Lonja (1428, 1430), posteriormente con Miquel Sagrera en la construcción de Nuestra Señora de Gracia (1449) (BARCELÓ y LlOMPART, 1998: 90-91, doc. 9) y, finalmente, con Antoni Sagrera, con quien trabajó en la construcción de la iglesia del convento de Jesús extramuros (CARBonell BuAdes, 2007-2008: 67) y en favor de quien Huguet Barxa actuó en una ocasión como testimonio (1460) (ARM, Protocolo C-115, f. 248v).

${ }^{62}$ Aguiló, 1905-1907: 30. ARM, Protocolo C-117, f. 50v. Su hijo se llamaba Nicolau y en 1461 sabemos que tenía una edad comprendida entre veinte y veinticinco años. 


\section{BIBLIOGRAFÍA}

Aguiló, Estanislao, "Notes i documents per una llista d'artistes mallorquins", $B S A L, 11,1905-1907$, pp. 2930.

Aloma Estever, Gabriel y Alomar Canyelles, Antoni, El patrimoni cultural de les illes Balears. Idees per una política de defensa i protección, IEB, 1994.

Armangué i Herrero, Joan, "Llegendes Alguereses al llegendari popular català (1926-1928)" en Valriu, Caterina; Armangué, Joan (a cura de), Els gèneres etnopoètics, Cagliari, Grafica del Parteolla, 2006, pp. 7-39.

Barceló Crespí, Maria, "Notes sobre els vilasclar, picapedres", BSAL, 49, 1993, pp. 127-140.

Barceló Crespí, Maria y Llompart, Gabriel, "Quaranta dades d'art medieval mallorquí", a BSAL, 54, 1998, pp. 85-104.

Barceló Crespí, Maria, "Nous documents sobre l'art de la construcció", BSAL, 59, 2003, pp. 221-247.

Bernís, Carmen, "La moda y las imágenes góticas de la Virgen. Claves para su fechación", Archivo Español de Arte, Tomo XLIII, núms. 169-172, 1970, pp. 193-218.

Carbonell, Xavier, La imatge de la música en les Illes Balears, Olañeta, Palma, 2004.

Carbonell Buades, Marià, "Sagreriana Parva”, Locvs Amoenvs, 9, 2007-2008, pp. 61-78.

Climent Guimerá, Federico (coord.), La Lonja de Palma, Palma, Govern de les Illes Balears, 2003.

Conrado de Villalonga, José Francisco, El Real Sitio de la Almudaina. Palacio de los Reyes de Mallorca, Madrid, Editora Patrimonio Nacional, 1992.

Español Bertran, Francesca, "La escultura tardogótica en la Corona de Aragón", en Actas del Congreso Internacional sobre Gil de Siloé y la Escultura de su época (Burgos 13-16 octubre de 1999), Burgos, Institución Fernán González/Academia Burgense de Historia y Bellas Artes, 2001, pp. 287-333.

Juan Vicens, Antònia, Els artesans de la pedra i l'escultura arquitectònica. Mallorca c. 1390-1520, Universitat de les Illes Balears, 2012 (Tesis doctoral inédita).

Llompart, Gabriel, "Miscelánea de arquitectura y plástica sacra mallorquina (Siglos XIII-XIV)", Analecta Sacra Tarraconensia, 1973, pp. 83-114.

Llompart, Gabriel, "Huguet Barxa, autor del retablo de Passio Imaginis de Felanitx (Mallorca)", Archivo Español del Arte, 50, 1977, pp. 328-335.

Llompart, Gabriel, La pintura medieval mallorquina. Su entorno cultural y su iconografia, 4 vols., Palma, Luís Ripoll, 1977-1980.

Llompart, Gabriel, "Identificación del Maestro de las predelas y encuadre de otros más", Estudis Baleàrics, 29/30, 1988, pp. 45-52.

Llompart, Gabriel, "Sagreriana Minora", BSAL, 39, 1983, pp. 407-434.

Llompart, Gabriel, "Més precisions sobre Huguet Barxa, imaginaire medieval", Estudis Baleàrics, 62/63, 1998-1999, pp. 53-59.

Llompart, Gabriel y Palou, Joana Maria, Nostra Dona Santa Maria dins l'art mallorquí, cat. exp., Palma, Govern Balear/Conselleria Educació i Cultura, 1988.

Llompart, Gabriel, Miscelánea documental de pintura y picapedrería medieval mallorquina, Palma, Museu de Mallorca, 1999.

Llompart, Gabriel y Palou, Joana Maria, "De portal a portal: inovació i tradició a l'escultura mallorquina del segle XV", Al tombant de l'Edat Mitjana (XVIII Jornades d'Estudis Històrics Locals, 1999), Palma, Institut d'Estudis Baleàrics, 2000, pp. 407-425.

López Iborra, Laura, "Macià Bonafè i altres tallistes del segle XV", L'Art gòtic a Catalunya. Escultura II. De la plenitud a les darreres influències foranes, Barcelona, Enciclopèdia Catalana, 2007a, pp. 190-199.

López Iborra, Laura, "El cadiram de Sant Francesc de Palma-Porreres, una obra mallorquina de Macià Bonafè", en Actes de les I Jornades d'Estudis Locals, Porreres, Ajuntament de Porreres, 2007b, pp. 27-43.

Manote Clivillés, Maria Rosa, L'escultura gotica catalana de la primera meitat del segle XV a la Corona d'Aragó: Pere Joan i Guillem Sagrera, Universitat de Barcelona, 1996 (Tesis doctoral inédita).

Manote, Maria Rosa, "Huguet Barxa (Atribuït). Lamentació o Plany sibre el Crist mort", en Mallorca gòtica, cat. exp., Palma/Barcelona, Govern Balerar/MNAC, 1998, pp. 259-261.

Muntaner Bujosa, Juan, "Para la historia de las Bellas Artes en Mallorca", BSAL, 31, 1962, pp. 17-18.

Arch. esp. arte, LXXXVII, 347, JULIO-SEPTIEMBRE 2014, 209-226

ISSN: 0004-0428, eISSN: 1988-8511, doi: 10.3989/aearte.2014.14 
Palou, Joana Maria, “Mestre anònim borgonyó del cercle de Sagrera. Àngel músic”, en Mallorca gòtica, cat. exp., Palma/Barcelona, Govern Balerar/MNAC, 1998, pp. 253-255.

Palou, Joana Maria, "Pere Morey, mestre major del portal del Mirador de la catedral de Mallorca", en Yarza, Joaquín y Fité, Francesc (editores), L'artista-artesà medieval a la Corona d'Aragó, Lleida, Universitat de Lleida/Institut d'Estudis Ilerdencs, pp. 385-397.

Pascual, Aina y Llabrés, Jaume, Conventos y monasterios de Mallorca. Historia, arte y cultura, Olañeta, Palma, 1992.

Piferrer, Pablo, Quadrado, José Maria, Islas Baleares, Palma, Ediciones Ayer, 1969.

Pons Cortés, Antonio y González Ansorena, Luis, "La sillería gótica del convento de San Francisco de Palma. Historia, topografía y aspectos iconográficos", Boletín Museo e Instituto Camón Aznar, 104, 2009, pp. 451-500.

Rosselló Vaquer, Ramon, Cronicó Felanitxer, XV, Felanitx, 1975.

Rosselló Vaquer, Ramon, Noticiari de Felanitx, 1228-1599, Felanitx, 1997.

Sabater, Tina, La pintura mallorquina del segle XV, Palma, UIB, 2002.

Sastre Moll, Jaume, La Seu de Mallorca (1390-1430). La prelatura del bisbe Lluís de Prades i d'Arenós, Palma, Lleonard Muntaner-Consell de Mallorca, 2007.

Serra Desfilis, Amadeo, "Al servicio de la ciudad: Joan del Poyo y la práctica de la arquitectura en Valencia (1402-1439)", Ars Longa, 5, 1994, pp. 111-119.

Terés Tomàs, Maria Rosa, "Maciá Bonafé y el coro de la catedral de Barcelona: nuevas consideraciones en torno a su intervención", Boletín Museo e Instituto Camón Aznar, 24, 1986, pp. 65-85.

Ysasi, Rafael de, Palma de Antaño a través de un cristal, Palma, Olañeta, 1998.

Fecha de recepción: 16-IX-2013

Fecha de aceptación: 10-III-2014

Arch. esp. arte, LXXXVII, 347, JULIO-SEPTIEMBRE 2014, 209-226

ISSN: 0004-0428, eISSN: 1988-8511, doi: 10.3989/aearte.2014.14 